\title{
AN ANALYSIS OF DIRECTIVE SPEECH ACTS IN THE FAULT IN OUR STARS MOVIE SCRIPT
}

by:

\author{
Febi Rosella Wijaya ${ }^{1}$ Jauhar Helmie ${ }^{2}$ \\ Suryakancana University \\ febirosellawijaya@gmail.com ${ }^{1}$ Jauharhelmie@ unsur.ac.id ${ }^{2}$
}

\begin{abstract}
Pragmatics is branch of linguistics studies that attracts the writer to learn more about it. This study aims to identify the directive speech acts performed in "The Fault in Our Stars" movie script. Moreover, this study investigated how often the direct speech acts performed and which type of directive speech acts that are most frequently used in the movie script. The writer uses qualitative research method by collecting data from read the movie script, analyzing the dialogues of each characters, watch the movie and read the library research. A total of 40 directive speech acts were successfully identified. The result of analysis shows that the illocutionary acts with directive speech acts of suggest is the most frequently in the movie script $(3,50 \%)$. The least frequently used locutionary with the directive speech acts of order in the movie script $(0,0 \%)$. This study is expected to give some useful insights in understanding what directive speech acts is. The writer hopes people can not only produce speech acts in their daily activities, but also understand why and how people react or response directive speech acts.
\end{abstract}

Keywords: Directive speech acts, movie script, dialogues, qualitative. 


\section{INTRODUCTION}

Language is a system, language is communication tools which built from the customs that are closely related to the place is located. People from different customs may speak different dialect or language. Every country or region has a different cultural which has influences to the language in that country or region. According to Halliday (1973), stated the purpose of language functions are instrumental function, regulatory function, representation function, the function of interaction, private function, heuristic function, and imaginative function.

In communication, we need partner or hearer to make our communication efficiently. Speaker and hearer usually use the same language to communicate so the message can get across easily. But in some communication case, the speaker could not get their message across due to a different cultural or divergences. Divergences may result the hearer get misunderstanding of what the speaker is talking about. Moreover, the message that may not deliver to be easily. Based on the case, it's possible to learn speech acts, so we can implement them in the daily social interaction of our life. Moreover, speech acts is the part of pragmatics.

Speech act refers to utterance and speech acts are the basic or the minimal units of linguistics communication. The study investigated the use of directive speech acts in the movie script. The movie script entitled The Fault in Our Stars by Josh Boone. The following research of the study are; How to analyze locutionary acts in The Fault in Our Stars movie script? How to analyze illocutionary acts in The Fault in Our Stars movie script? How to analyze perlocutionary acts in The Fault in Our Stars movie script?

The aims of the study are; to make the reader understand more about directive speech acts, the reader also can learn about words and utterances. The reader can learn about speech acts by observing literary work, such as poem, movie, magazine, newspaper, and movie script, and the writer hopes the reader is not only can read or analyze the directive speech acts in the literary work, but also can make a literary work by using speech acts as the element. 


\section{THEORETICAL FRAMEWORKS}

Author: Febi Rosella Wijaya and Jauhar Helmie

There are some theories underpinning this resume. Most of them are related to pragmatics, speech acts, speech acts classification, and definition of script. Each of them is explained below.

\section{a. Definition of Pragmatics}

People cannot really understand the nature of a language unless they understand how it is used in communication. It is important for people to understand language because it always expresses ideas, thought, feelings, and the speaker's intention. One branches of linguistics which studies language as being used is called pragmatics.

According to Yule (1996: 3), pragmatics is concerned with the study of meaning as communicated by a speaker or writer and interpreted by a listener or reader. It has, consequently, more to do with the analysis of what people mean by their utterances than what the words or phrases in those utterances might mean by themselves. Pragmatics is the study of speaker meaning. Similarly, according to Yule (1996:3), this approach also necessarily explores how listeners can make inferences about what is said in order to arrive at an interpretation of the speaker's intended meaning. This type of study explores how a great deal of what is unsaid is recognized as part of what is communicated. We might say that it is the investigation of invisible meaning. Pragmatics is the study of how more gets communicated than is said.

\section{b. Speech Acts}

According to Searle (1976: 16), speech acts are the basic or the minimal units of linguistics communication. Furthermore, Austin (1960: 52) added that speech acts refers to an utterance and also the total in which the utterance is issued. Moreover, according to Yule (1996) stated, speech acts is action performed via utterances. These descriptive terms for different kinds of speech acts apply to the speaker's communicative intention in producing an utterance. The speaker normally expects that his or her communicative intention will be recognized by the hearer. Both speaker and hearer are usually helped in this process by the circumstances surrounding the utterance. 
On any occasion, the action performed by producing an utterance will consist of three related acts. There is first a locutionary act, which is the basic act of utterance, or producing a meaningful linguistic expression. Mostly we don't produce wellperformed utterances with no purpose. We form an utterance with some kind of function in mind. This is the second dimension, or the illocutionary act. The illocutionary acts is performed via the communicative purpose. We do not, of course, simply create an utterance with a function without intending it to have an effect. This is the third dimension, the perlocutionary act (Yule, 1996).

\section{c. Speech Acts Classification}

According to Yule (1996: 53), one general classification system lists five types of general function performed by speech acts: declarations, representatives, expressive, directives, and commissives.

According to Yule (1996), declaration are those kinds of speech acts that change the world via utterance. Representatives are those kind of speech acts that state what the speaker believes to be the case or not. Expressives are those kinds of speech acts that state what the speaker feels. Directives are those kind of speech acts that speaker use to get someone else to do something. They express what the speaker wants. They are commands, orders, request, and suggestions. Commissives are those kinds of speech acts that speakers use to commit themselves to some future action.

\section{d. The Definition of Script}

According to Longman Dictionary of American English, script is written form of a play, film, or broadcast. In addition, according to Kamus Besar Bahasa Indonesia (KBBI, 2007) script is "Karangan yang masih ditulis oleh tangan, karangan seseorang sebagai karya hasil, bahan-bahan berita yang siap di set" [The framework that still written by hand by someone as the work proceeds, the news materials prepared in a set] (Kamus Besar Bahasa Indonesia, 2007).

\section{METHOD}


Author: Febi Rosella Wijaya and Jauhar Helmie

This research used qualitative descriptive research as the research design. The writer chose The Fault in Our Stars as the data resource, because in this case, the writer found there is no previous study analyzed literary work, such as movie script. The writer collected the data and made table to classify the data. Analysis on locutionary acts, illocutionary cats, and perlocutionary acts aspects of directive speech acts was described in each category.

All the data collected from this research are tabulated and analyzed based on their directive speech acts sub-categories. Directive speech acts consists of four categories, i.e. commands, suggests. Orders, and requests. Then it was described by applying the theory related to the data.

\section{FINDINGS AND DISCUSSION}

The table data is the directive speech acts table. The table consists of character analysis of each characters, based on the The Fault in Our Stars movie script, and also the dialogues that interpreted directive speech acts. Speech acts Colum; Locutionary acts (LC), illocutionary acts (ILC), and perlocutionary acts (PLC), and sub-categories of directive speech acts; suggest $(\mathrm{S})$, orders $(\mathrm{O})$, Commands ( $\mathrm{C}$ ), and request ( $\mathrm{R}$ ).

\begin{tabular}{|c|c|c|c|c|c|c|c|c|c|}
\hline \multirow[t]{2}{*}{ No } & \multirow[t]{2}{*}{ Character } & \multirow[t]{2}{*}{ Dialouges } & \multicolumn{3}{|c|}{ Speech Acts } & \multicolumn{4}{|c|}{ Sub-Categories } \\
\hline & & & $\mathbf{L C}$ & ILC & PLC & $\mathbf{S}$ & $\mathbf{O}$ & C & $\mathbf{R}$ \\
\hline 1 & $\begin{array}{l}\text { Give it a chance, } \\
\text { who knows you } \\
\text { might even find it } \\
\text { enlightening }\end{array}$ & Doctor Maria & $\sqrt{ }$ & & & $\sqrt{ }$ & & & \\
\hline 2 & $\begin{array}{l}\text { yeah. We are } \\
\text { going } \\
\text { downstairs. Bye }\end{array}$ & $\begin{array}{l}\text { Augustust } \\
\text { Waters }\end{array}$ & $\sqrt{ }$ & & & & & & $\sqrt{ }$ \\
\hline 3 & $\begin{array}{l}\text { come on, we've } \\
\text { been through } \\
\text { this. You need to }\end{array}$ & Mrs. Lancaster & $\sqrt{ }$ & & & & & $\sqrt{ }$ & \\
\hline
\end{tabular}




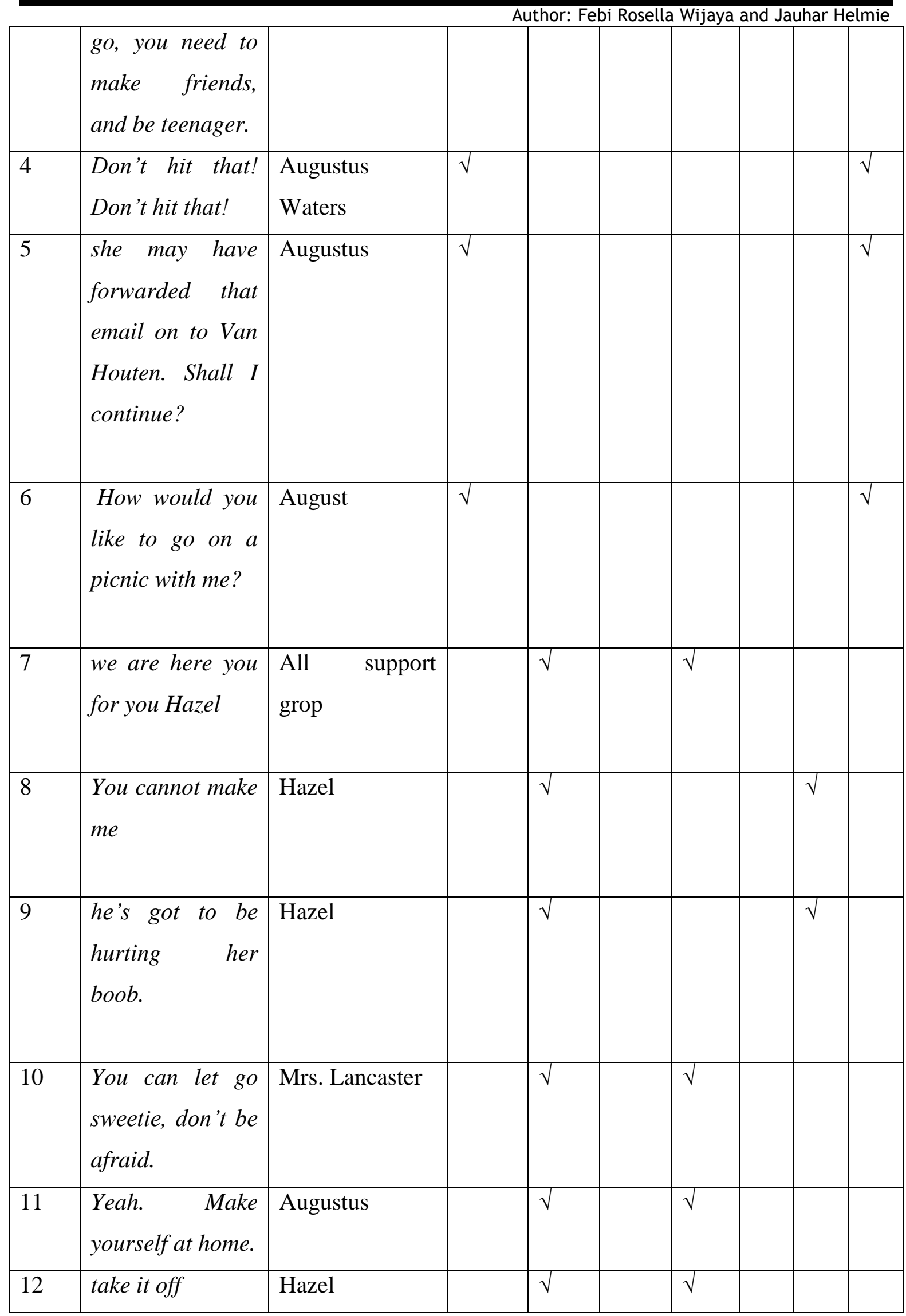




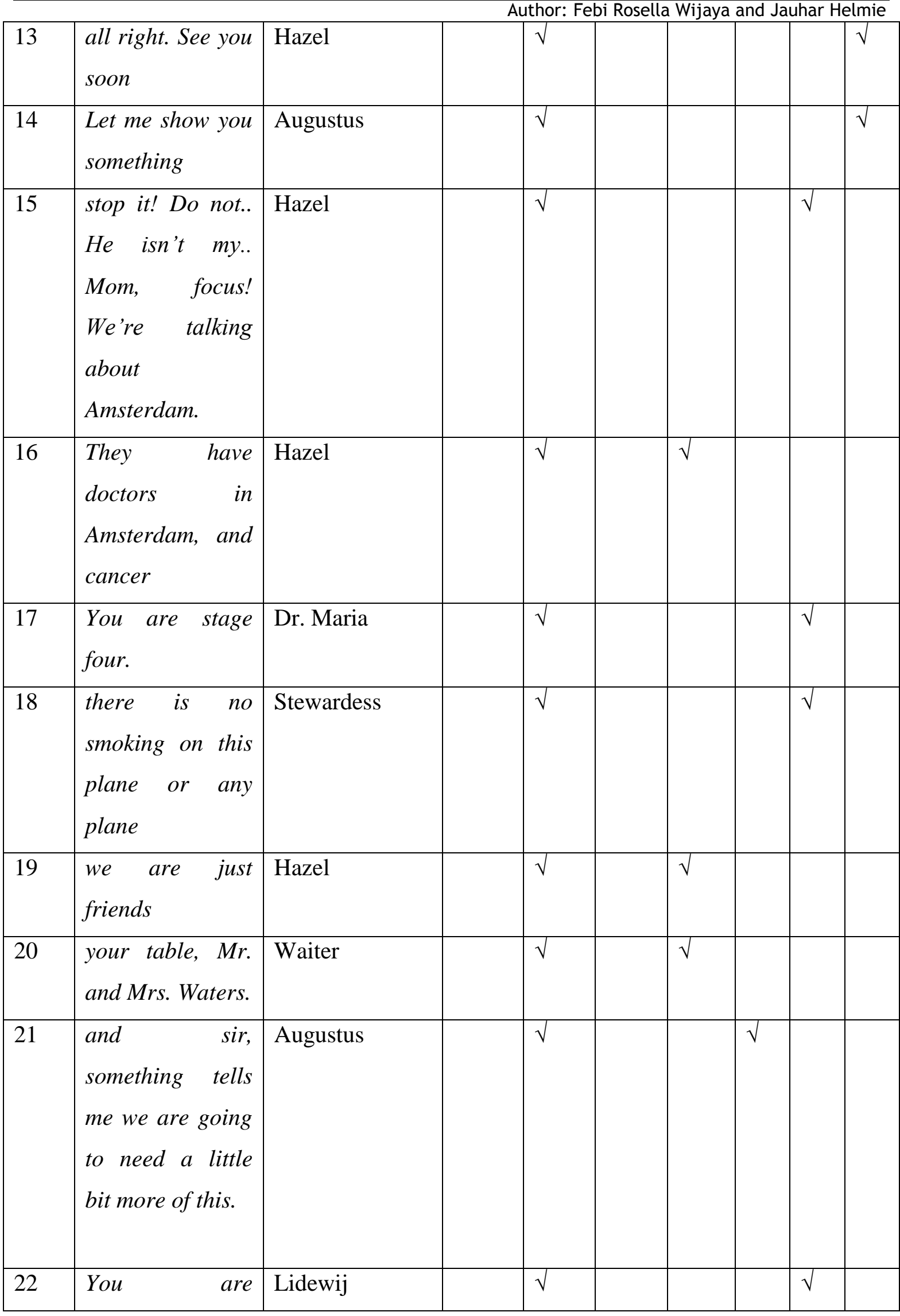




\begin{tabular}{|c|c|c|c|c|c|c|c|}
\hline & & & \multicolumn{5}{|c|}{ Author: Febi Rosella Wijaya and Jauhar Helmie } \\
\hline & American & & & & & & \\
\hline 23 & $\begin{array}{l}\text { I am not going } \\
\text { anywhere with } \\
\text { that man. }\end{array}$ & Hazel & $\sqrt{ }$ & & $\sqrt{ }$ & & \\
\hline 24 & $\begin{array}{l}\text { there are many } \\
\text { stairs. } \\
\text { stairs }\end{array}$ & Lidewij & $\sqrt{ }$ & & & $\sqrt{ }$ & \\
\hline 25 & $\begin{array}{l}\text { don't worry, take } \\
\text { your time. }\end{array}$ & Augustus & $\sqrt{ }$ & & $\sqrt{ }$ & & \\
\hline 26 & $\begin{array}{l}\text { Gus, get over } \\
\text { yourself }\end{array}$ & Hazel & $\sqrt{ }$ & & $\sqrt{ }$ & & \\
\hline 27 & $\begin{array}{l}\text { they are gonna } \\
\text { stop the chemo }\end{array}$ & Mrs. Waters & $\sqrt{ }$ & & & $\sqrt{ }$ & \\
\hline 28 & $\begin{array}{l}\text { hey, it's a good } \\
\text { life, } \\
\text { Grace. }\end{array}$ & Augustus & $\sqrt{ }$ & & $\sqrt{ }$ & & \\
\hline 29 & $\begin{array}{l}\text { losing you, that } \\
\text { is going to hurt } \\
\text { like hell. But you } \\
\text { of all people } \\
\text { know it's } \\
\text { possible to live } \\
\text { with pain. Just } \\
\text { do it }\end{array}$ & Mrs. Lancaster & $\sqrt{ }$ & & & $\sqrt{ }$ & \\
\hline 30 & $\begin{array}{l}\text { I'll see you soon. } \\
\text { Drive safe. }\end{array}$ & Mrs. Lancaster & $\sqrt{ }$ & & & $\sqrt{ }$ & \\
\hline 31 & your turn Gus & Patrick & & $\sqrt{ }$ & & & $\sqrt{ }$ \\
\hline 32 & $\begin{array}{l}\text { Mom, look at } \\
\text { this! Come here! }\end{array}$ & Hazel Grace & & $\sqrt{ }$ & & $\sqrt{ }$ & \\
\hline
\end{tabular}




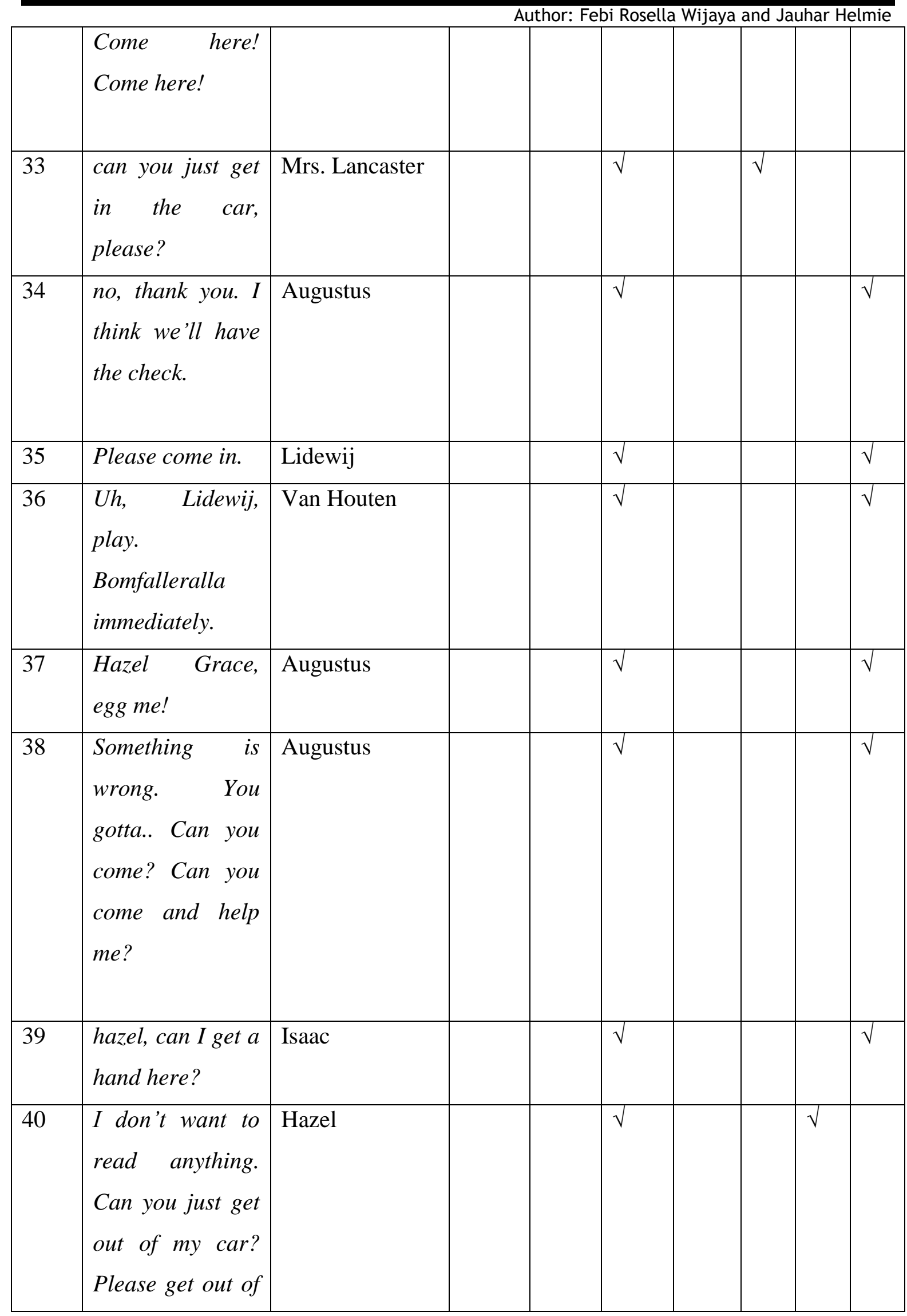




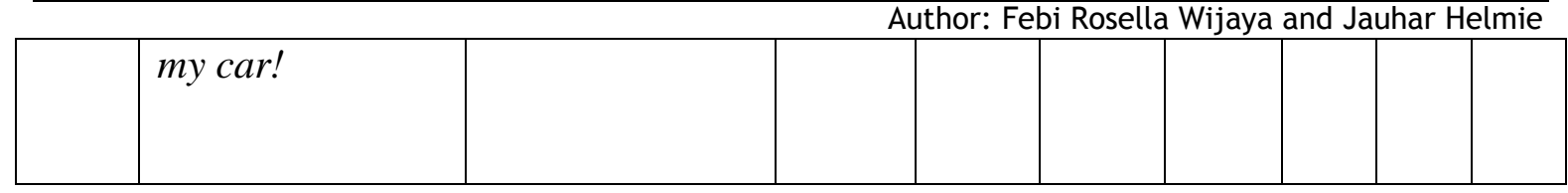

Table 1: Analysis of Speech Acts and Directive Speech acts

The table was presented data finding through the study. Based on the data the most frequently of directive speech act is request with $3,50 \%$ percentage. The next frequently is suggests with total $2,33 \%$ percentage in the movie script, the least frequently is order with $0,0 \%$ percentage.

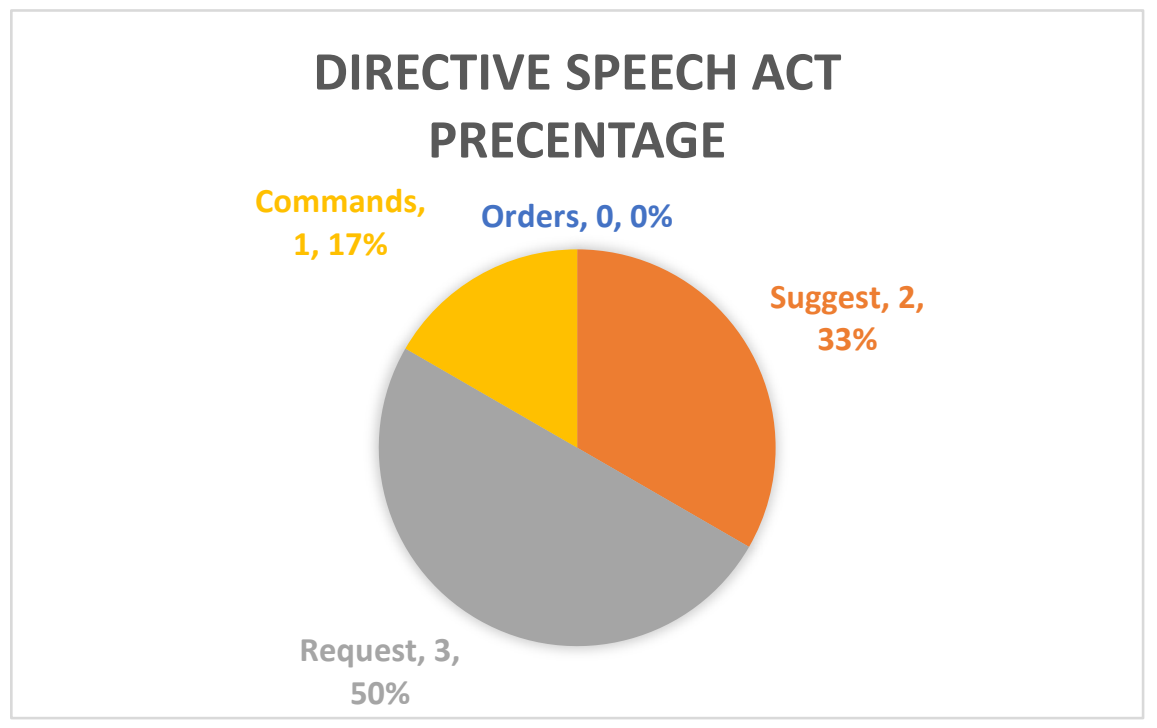

Figure 1. Directive Speech Act Percentage.

\section{Conclusion}

Based on the data analysis, the directive speech act are frequently performed in the movie script. It can be seen from the tables in the previous chapter that elaborate the use of directive speech acts. The diagram show that 40 directive speech act are performed in the movie script. The diagram summary show that directive speech act of request is the most frequently in the movie script $(3,50 \%)$. The percentage shows the most frequently used directive speech acts by calculating the percentage of each category of directive speech acts. While the least used directive speech acts are the directive speech act of order $(0 \%)$.

\section{Suggestion}


The writer hopes that many people will benefit from watching the movie not just for entertainment but also for study. Many literary works can be learned, such as magazine, poems, movie, and also movie script itself. The study in this thesis focused on the directive speech acts. More comprehensive research on the aspects of locutionary acts, illocutionary acts, and perlocutionary acts in this movie script will be very interesting to do. Through this study will have better understanding why and how people react or response directive speech acts based on their perspective. People not only can produce the speech acts, but also make some interesting literary works through speech acts.

\section{REFERENCES}

Austin, J. L. (1962). How to do Things with Words (2th Ed.). London: Routedge.

Bloomfield (1993). Language. New York: Henry Holt \& Co.

Cambridge Academic Content Dictionaries Online. 2008: Cambridge University

Press. Retrieved from:

http://dictionary.cambridge.org/esdiccinario/ingles/multiword-verbs. http://dictionary.cambridge.org/esdiccinario/ingles/prepositional-verbs. http://dictionary.cambridge.org/esdiccinario/ingles/phrasal-preposition-verbs. [Accessed: 09.06.16]

Chomsky, N. (2006). Language and Mind. New York: Cambridge University Press.

Creswell, J.W. (2012). Educational Research: Planning, Conducting, and Evaluating Qualitative and Quantitative Research. Boston: Edward Brothers Inc. 
Elliot, J. (2005). Using Narrative in Social Research Qualitative and Quantitative Approaches. London: Sage Publication.

Grice, H.P. (1989). Studies in the Way of Words. UK: Harvard University Press.

Halliday (1973). Exploration in Language Function. London: Edward Arnol.

Halliday \& Hasan. (1976). Cohesion in English. London: Longman.

Holmes, J. (2001). An Introduction to Sociolinguistics. London: Longmans.

Justove, F. (2006). Direct and Indirect Speech Acts in English. Brno: Faculty of Arts Department of English and American Studies Masaryk University in Brno. Retrieved from:

http://www.academia.edu/7525137/Direct_and_Indirect_Speech_Acts_in_English _Major_Bachelors_Thesis [Assessed on 12 February 2016]

Leongkamchorn, S. (2010). Speech Act Analysis of British and American Poetry. Bangkok: School of Language and Communication. Unpublished. Retrieved from: Libdcms.nida.ac.th [Assessed on 12 February 2016]

Leech, G.N. (1983). Principles of Pragmatics. London: Longman.

Levinson, S.C. (1983). Pragmatics. Cambridge, England: Cambridge University.

Made, D. et al,. (2012). An Analysis of Speech Acts in The Conversation between Habibie and Ainun in The Film Habibie and Ainun. Singaraja: Ganesha University. Unpublished. Retrieved from:

http://download.portalgaruda.org/article.php?article $=259601 \& v a l=7035 \&$ title $=$ An \%20Analysis\%20of\%20Speech\%20Acts\%20in\%20the\%20Conversation\%20betw een $\% 20$ Habibie $\% 20$ and\%20Ainun\%20in\%20the\%20Film\%20Entitled\%20Habibi e\%20and\%20Ainun\%202012

[Assessed on 12 February 2016]

Webster, Merriam. (2011). Merriam-Webster Dictionary Application: Merriam Webster Inc

McMillan. J, H. (1996). Educational Research Fundamentals for the Consumer $\left(2^{\text {nd }}\right.$ Edition). Virginia Commonwealth University, HarperCollins. College Publishers Mey, J.L. (1993). An Introduction Pragmatics. USA: Blackwell Publishing. 
Miles, M.B. \& Huberman, A.M. (1994). Qualitative Data Analysis (2 ${ }^{\text {nd }}$ edition). Thousand Oaks, CA: Sage Publication.

Nazir, M. (1998). Metode Penelitian. Jakarta: Ghalia Indonesia.

Neustadter, S. \& Weber. (2013). the Fault in Our Stars. Los Angeles: Fox 2000 Pictures. Published on September 2013. Retrieved from:

Dailyscript.com [Assessed on 12 February 2016]

Odden, D. (2005). Introducing Phonology. New York: Cambridge University Press.

Richard, Jack, et al. (1985). Longman Dictionary of Applied Linguistics. England: Longman Group Limited

Searle, J. R. (1975). Speech Act Theory an Pragmatics. Holland: D. Reidel Publishing Company.

Santoso, I. et al. (2012). Speech Act on Short stories: A Pragmatic Study. Bandung: Padjajaran University. Published on February 2012. Retrieved from: http://www.tijoss.com/19\%20volume/10Imam\%20santoso.pdf. [Assessed on 12 February 2016]

Tim Penyusun Pusat Kamus. (2007). Kamus Besar Bahasa Indonesia (KBBI). Jakarta: Balai Pustaka.

Tood, L. (1987). And Introduction to Linguistic. England: Longman

Tsui, A.B.M. (1994). English Conversation. Oxford: Oxford University Press.

Wardhaugh, R. (2006). An Introduction to Sociolinguistics. USA: Blackwell Pulishing Yule, G. (1996). Pragmatics. New York: Oxford University Press. 
Volume 7 Nomer 01 Maret 2019

ISSN 2338-3739 (Print)

ISSN 2614-8099 (online)

https://jurnal.unsur.ac.id/jeopallt

Author: Febi Rosella Wijaya and Jauhar Helmie 
Volume 7 Nomer 01 Maret 2019

ISSN 2338-3739 (Print)

ISSN 2614-8099 (online)

https://jurnal.unsur.ac.id/jeopallt

Author: Febi Rosella Wijaya and Jauhar Helmie 
Volume 7 Nomer 01 Maret 2019

ISSN 2338-3739 (Print)

ISSN 2614-8099 (online)

https://jurnal.unsur.ac.id/jeopallt

Author: Febi Rosella Wijaya and Jauhar Helmie 